\title{
Thioploca araucae sp. nov. and Thioploca chileae sp. nov.
}

\author{
S. MAIER ${ }^{1 *}$ AND V. A. GALLARDO ${ }^{2}$ \\ Department of Zoological and Biomedical Sciences, Ohio University, Athens, Ohio 45701, ${ }^{1}$ and Departamento de \\ Oceanología, Universidad de Concepción, Concepción, Chile ${ }^{2}$
}

\begin{abstract}
Like all members of the genus Thioploca, two new marine thioplocas from the benthos of the Chilean continental shelf were found to be colonial, multicellular, gliding trichomes of uniform diameter enclosed by a common sheath. However, the cellular sulfur inclusions were located in the thin peripheral cytoplasm surrounding a large, central vacuole. Gliding motility of these organisms did not persist in diluted seawater, under fully aerobic conditions, or in anaerobic atmospheres. Low concentrations of sulfide $(100 \mu \mathrm{M})$ were beneficial. The trichome diameters of Thioploca araucae ranged from 30 to $43 \mu \mathrm{m}$, and those of Thioploca chileae ranged from 12 to $20 \mu \mathrm{m}$. Neither species has been isolated in pure culture.
\end{abstract}

In 1963, Gallardo (1) discovered in the benthos of the continental shelf off Chile at a depth of 100 to $280 \mathrm{~m}$ an extensive, filamentous, microbial biomass which was labeled "bluegreen algae," but was later (2) correctly identified as consisting largely of Thioploca spp. Generic identification was made microscopically on the basis of the unique, characteristic morphology of members of this genus. This was the first report of marine thioplocas. Our observations and those of other workers (7) verified that the range of these marine thioplocas extended from the Gulf of Arauco in central Chile to latitude $6.5^{\circ} \mathrm{S}$ in northern Peru. By following the pattern of species identification in freshwater thioplocas (6), one of us (V.A.G.) identified three different thioplocas in the benthos (2). In this paper we characterize two of these marine thioplocas, neither of which has been isolated in pure culture.

\section{MATERIALS AND METHODS}

Grab samples of sediments containing Thioploca taken at depths of 80 to $100 \mathrm{~m}$ due west of Dichato, Chile (latitude, $36^{\circ} 31^{\prime} 30^{\prime \prime} \mathrm{S}$; longitude, $72^{\circ} 56^{\prime} 40^{\prime \prime} \mathrm{W}$ ), were maintained at $8^{\circ} \mathrm{C}$. The large sheathed bundles of Thioploca were gently teased from the sediment and washed in filtered (Whatman no. 2 paper) seawater. Microscopy was used to select samples of the two forms (trichome diameters, 12 to 20 and 30 to $43 \mu \mathrm{m})$ and to reject all nongliding fascicles. Samples for photomicroscopy (Leitz Ortholux microscope equipped with an Orthomat camera; Ilford PanF film) were fixed with glutaraldehyde (final concentration, 2.5\%) before wet mounts were made. Macrophotography was done with a Pentax camera equipped with a $50-\mathrm{mm}$ f 2.8 macro lens and Ilford PanF film.

Thioploca bundles intended for transmission electron microscopy were prefixed in $0.1 \%$ osmium tetroxide in 4 volumes of filtered seawater plus 1 volume of distilled water for $30 \mathrm{~min}$, washed in the same dilution of filtered seawater, fixed overnight at $18^{\circ} \mathrm{C}$ in a mixture containing $0.5 \mathrm{ml}$ of $5 \%$ aqueous osmium tetroxide and $2.0 \mathrm{ml}$ of modified buffer of Kellenberger et al. (3) (10 volumes of buffer base, 14 volumes of $\mathrm{HCl}, 19.7$ volumes of filtered seawater, 6.3 volumes of distilled water, 0.5 volume of $11 \%$ aqueous $\mathrm{CaCl}_{2}$ ), washed in 4 volumes of modified buffer diluted with 1 volume of distilled water (dilute buffer), stained with $0.5 \%$ uranyl acetate in dilute buffer for $2 \mathrm{~h}$ at room temperature, and washed in dilute buffer. The dilute buffer containing the

\footnotetext{
* Corresponding author.
}

Thioploca bundles was gradually diluted until, after $3 \mathrm{~h}$, the bundles were in distilled water. They were then cut into $1-$ to $2-\mathrm{mm}$ sections and subjected over $16 \mathrm{~h}$ to a gradual acetone dehydration series (maximum single acetone difference, $\leq 7 \%$ ), followed by three $(1 \mathrm{~h})$ changes in dried acetone, gradual transfer to propylene oxide, and gradual infiltration and embedding in Epon. Sections were cut with glass knives. Thick sections were stained with toluidine blue. Thin sections on 200-mesh copper grids were stained with lead citrate (8) and examined with a Siemens Elmiskop IA electron microscope at $80 \mathrm{kV}$.

Since these organisms have not been grown in pure or mixed culture in the laboratory, the only observable characteristic which was indicative of an active physiological state was gliding motility. Therefore, retention of gliding motility under test conditions was taken as an indication of survival. Sediment samples containing thioplocas were placed into 50$\mathrm{ml}$ beakers, overlaid with 40 -ml portions of dilutions of seawater $(90,80,60,40$, and $20 \%$ dilutions plus tap water only), and incubated at $18^{\circ} \mathrm{C}$. Samples were examined daily microscopically. Washed bundles of gliding thioplocas were placed into $2.5 \mathrm{ml}$ of filtered seawater supplemented with 0 , 100,500 , and $1,000 \mu \mathrm{M}$ (final concentrations) sodium sulfide in tubes $(16$ by $100 \mathrm{~mm}$ ). Tubes to be incubated at reduced oxygen tensions were flushed with nitrogen and closed with Vacuject stoppers. Varying percentages of the gas phase $(0,2$, 5 , and $10 \%$ ) were replaced with air. An additional set was incubated aerobically. Duplicate tubes of each combination were incubated at $18^{\circ} \mathrm{C}$, and the contents were examined microscopically after 24 and $48 \mathrm{~h}$, respectively.

\section{RESULTS}

The large size of these colonial organisms made recovery easy. Even macroscopic observation revealed individual trichomes gliding out of the common sheaths (Fig. 1). Under the microscope more detail became apparent. Several trichomes, often in thick fascicles, were surrounded by a common sheath (Fig. 2, 4, and 6). The sheaths, which were mostly encrusted with detritus, were in the form of single or composite cylinders. Each trichome was composed of a single row of cylindrical or slightly barrel-shaped cells of uniform diameter (Fig. 2, 4, 5, and 7), except for some terminal segments which were tapered (Fig. 3 and 5). The individual cells appeared to be hollow (Fig. 3), and the numerous sulfur inclusions seemed to be located in a peripheral cytoplasmic shell (Fig. 5). The diameters of the trichomes fell into the following two, clearly separated size 

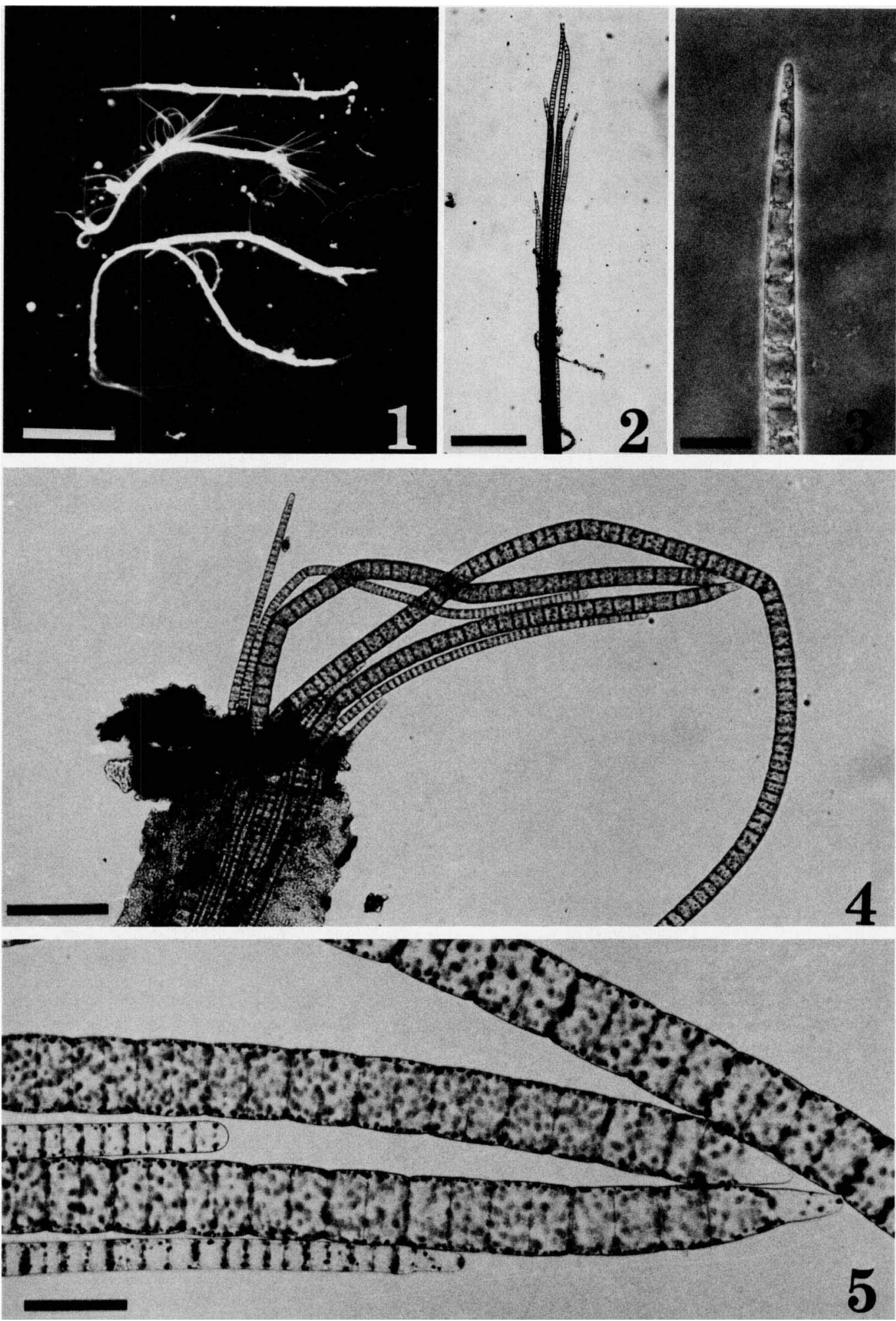

FIG. 1. Marine thioplocas washed clean of sediments. Trichomes have emerged from the end of and breaks in the sheath. Photomacrograph. Bar $=5 \mathrm{~mm}$.

FIG. 2. Terminal portion of a sheath with emerging trichomes of $T$. chileae. Bright-field microscopy. Bar $=250 \mu \mathrm{m}$.

FIG. 3. Tapered terminal segment of a trichome of $T$. chileae. Vacuoles are apparent in some of the cells. Phase-contrast microscopy. Bar $=25 \mu \mathrm{m}$.

FIG. 4. Terminal portion of a sheath with emerging trichomes of $T$. araucae and $T$. chileae. Bright-field microscopy. Bar $=200 \mu \mathrm{m}$.

FIG. 5. Enlarged portion of Fig. 4. Tapered and nontapered terminal segments are shown. A peripheral location for the relatively small, numerous sulfur inclusions is suggested. Bright-field microscopy. Bar $=50 \mu \mathrm{m}$. 

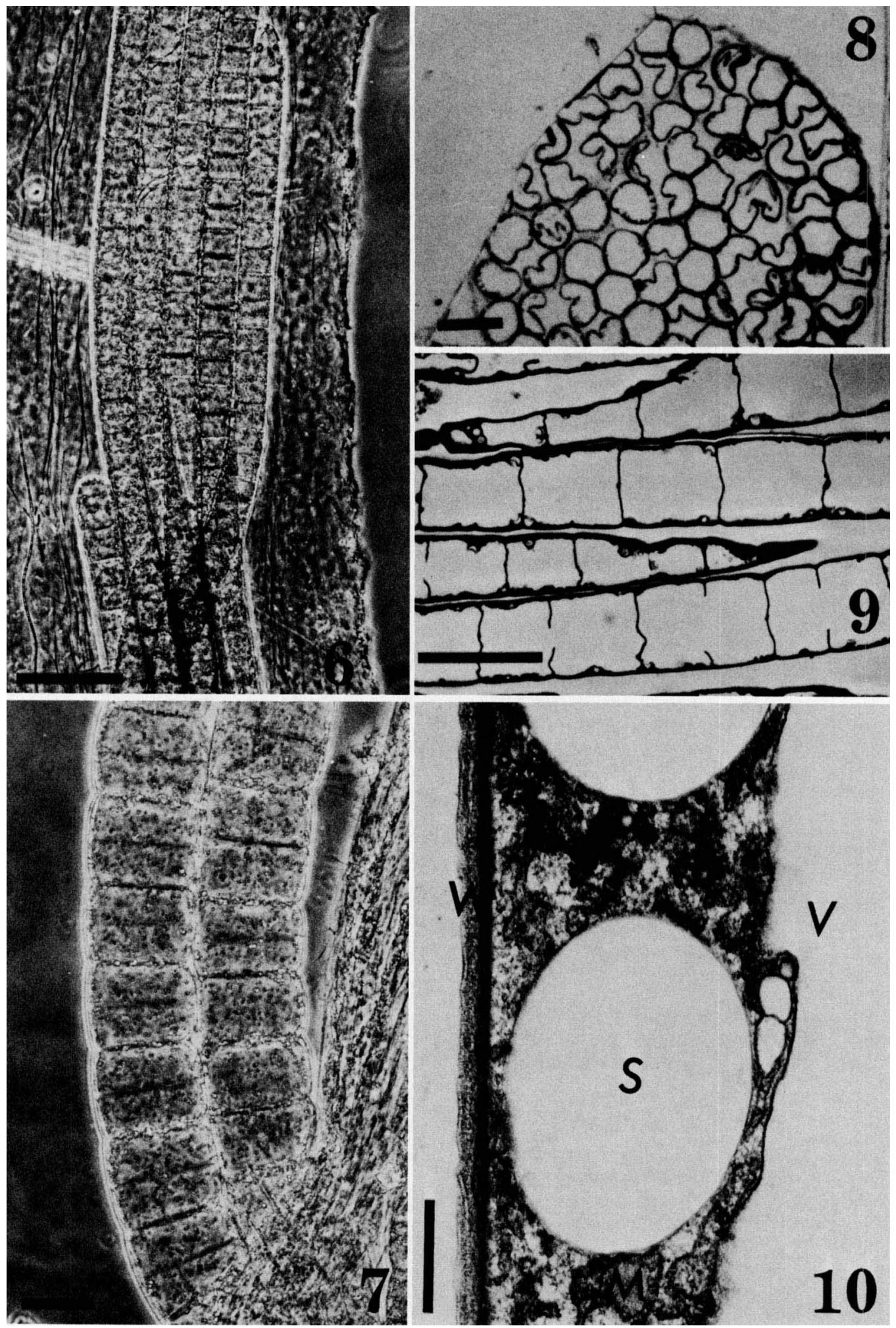

FIG. 6. T. araucae trichomes braided inside the sheath. Phase-contrast microscopy. Bar $=100 \mu \mathrm{m}$

FIG. 7. Portions of two trichomes of $T$. araucae which have emerged from their sheath. Phase-contrast microscopy. Bar $=25 \mu \mathrm{m}$.

FIG. 8. Cross-section of part of a sheathed fascicle of $T$. chileae. Some of the trichomes are collapsed. The large central vacuoles are obvious. Thick Epon section, toluidine blue stained. Bar $=25 \mu \mathrm{m}$.

FIG. 9. Longitudinal section of part of a sheathed fascicle of $T$. chileae. The thin peripheral cytoplasm and the centripedal septal development are apparent. Thick Epon section, toluidine blue stained. Bar $=25 \mu \mathrm{m}$.

FIG. 10. Electron micrograph of a thin longitudinal Epon section of the peripheral cytoplasmic cylinder of $T$. araucae, showing sulfur inclusions (S), ramifying intracytoplasmic membrane $(\mathrm{M})$, multi-layered cell wall $(\mathrm{W})$, and vacuole $(\mathrm{V})$. Uranyl and lead stained. Bar $=500$ $\mathrm{nm}$. 
groups: 12 to $20 \mu \mathrm{m}$ and 30 to $43 \mu \mathrm{m}$ (Fig. 2 and 5 through 7). The respective lengths of the individual cells were 7 to 26 and 11 to $36 \mu \mathrm{m}$. The fascicles of trichomes within a sheath were composed of one size group (Fig. 2 and 6). Occasionally, a mixture of the two size groups (Fig. 4 and 5) was observed. Embeddings for transmission electron microscopy confirmed the cell structure suspected on the basis of light microscopic examination. The center of each cell was occupied by a large vacuole which was surrounded by a thin cytoplasmic shell containing sulfur inclusions (Fig. 8 and 9). A multilayered cell wall surrounded the trichome, and the cytoplasm was traversed by numerous membrane intrusions (Fig. 10).

Survival studies showed cessation of gliding motility of trichomes in $40 \%$ and lower concentrations of seawater in less than $24 \mathrm{~h}$. In $60 \%$ and higher concentrations of seawater gliding persisted for more than 8 days. Of the four concentrations of sulfide tested, three were clearly unsuitable. In $1,000,500$, and $0 \mu \mathrm{M}$ sulfide, trichome motility did not persist for $24 \mathrm{~h}$, regardless of the incubation atmosphere. In $100 \mu \mathrm{M}$ sulfide the following observations were made: (i) under aerobic or anaerobic conditions trichome motility did not persist for $24 \mathrm{~h}$; (ii) in atmospheres containing 2 or $10 \%$ air in nitrogen, trichomes glided for $24 \mathrm{~h}$; and (iii) in atmospheres containing $5 \%$ air in nitrogen, trichome motility persisted for $48 \mathrm{~h}$.

\section{DISCUSSION}

Members of the genus Thioploca can be identified unequivocally on the basis of their characteristic morphology (from one to many gliding, multicellular trichomes of uniform diameter, with sulfur inclusions, within a common sheath) and their sedimentary habitat. No other organism combines these characteristics. The organisms described here differ from other species of Thioploca (6) by their obligately marine nature, by their vacuolated cells, and by the diameters of their trichomes. These organisms clearly fell into two distinct, nonoverlapping size groups. Size differences have been used in the past to separate noncultivable representatives into species $(5,6)$.

The occurrence of trichomes of two distinct diameters within a common sheath led to the naming of a separate dimorphic species (4). Our observations have shown (unpublished data) that thioplocas exist in a narrowly defined niche in the sediment. Changes in oxygen or sulfide concentrations resulted in relocation of the gliding trichomes in a new, suitable sediment horizon. Free trichomes can associate and glide along each other regardless of their diameters. As a result, the colonial, sheathed habit can be reacquired by whatever mixture of trichome diameters happens to be present. The result of such a chance association of two trichome diameters cannot constitute a separate species. However, the existence of such mixtures in the same environment that contains also sheathed fascicles of one size group only argues forcefully for the constancy of the trichome diameter characteristic. Indeed, some grab samples contained only pure fascicles of Thioploca araucae, whereas others contained only fascicles of Thioploca chileae. However, when pure fascicles of both species were found in the same sample, mixed fascicles were also found. Therefore, we suggest that the frequency of occurrence of mixed colonies is a function of both thioploca density and simultaneous presence of at least two species, as well as fluctuations of environmental conditions.

Apparently, both marine species require low concentrations of sulfide and oxygen. We have shown previously
(Arch. Microbiol., in press) by using autoradiography that in the presence of sulfide these marine thioplocas incorporate carbonate, as well as some forms of organic carbon, which suggests mixotrophic nutrition. Since these marine thioplocas are so easily and unmistakably identified microscopically, we offer the following, mostly morphological descriptions of these two new species of Thioploca.

Thioploca araucae sp. nov. (a.rau'cae. M.L. gen. n. araucae of Arauco.) Flexible, uniseriate trichomes made up of numerous, vacuolated cells, generally with numerous sulfur inclusions, occur in parallel or braided fascicles, which are enclosed by a common sheath of variable width. The number of trichomes within a sheath is variable. The sheath is frequently encrusted with detritus. Individual trichomes show independent gliding movement, and they may emerge from the ends of sheaths or from breaks in a sheath. The long trichomes are of uniform diameter, and their terminal segments are often tapered. Trichome diameters are 30 to $43 \mu \mathrm{m}$. Cell length, exclusive of the terminal cell, varies from 11 to $36 \mu \mathrm{m}$. The trichomes in a sheath may be accompanied by trichomes of other thioplocas with different diameters. Obligately marine; microaerophilic. Identified from the benthos of the Pacific Ocean South American continental shelf. Not isolated in pure culture.

Thioploca chileae sp. nov. (chi'le.ae. M.L. gen. n. chileae of Chile.) Flexible, uniseriate trichomes made up of numerous, vacuolated cells, generally with numerous sulfur inclusions, occur in parallel or braided fascicles, which are enclosed by a common sheath of variable width. The number of trichomes within a sheath is variable. The sheath is frequently encrusted with detritus. Individual trichomes show independent gliding movement, and they may emerge from the ends of sheaths or from breaks in a sheath. The long trichomes are of uniform diameter, and their terminal segments are often tapered. Trichome diameters are 12 to 20 $\mu \mathrm{m}$. Cell length, exclusive of the terminal cell, varies from 7 to $26 \mu \mathrm{m}$. The trichomes in a sheath may be accompanied by trichomes of other thioplocas with different diameters. Obligately marine; microaerophilic. Identified from the benthos of the Pacific Ocean South American continental shelf. Not isolated in pure culture.

Characteristics which qualify both species for inclusion in the genus Thioploca. The following characteristics qualify $T$. araucae and T. chileae for inclusion in the genus Thioploca: flexible, uniseriate, multicellular, independently gliding trichomes with sulfur inclusions, enclosed by a common sheath; uniform diameter of trichomes except for terminal segments; found in the upper layers of sediments.

Characteristics essential for membership in the respective species. The following characteristics are essential for membership in the species $T$. araucae: obligately marine; trichome diameter of 30 to $43 \mu \mathrm{m}$; vacuolated cells. The following characteristics are essential for membership in the species $T$. chileae: obligately marine; trichome diameter of 12 to $20 \mu \mathrm{m}$; vacuolated cells.

Diagnostic characteristics. The following characteristics are diagnostic: uniform, specific trichome diameter; vacuolated cells; common sheath; sulfur inclusions; gliding movement; lack of obvious pigments; isolated from marine sediments.

\section{ACKNOWLEDGMENTS}

We are grateful for support by grant INT-8017749 from the National Science Foundation Latin American Cooperative Program and by grants from the Chilean Comisión Nacional de Investigación Científica y Technológica and the Dirección de Investigación de Universidad de Concepción, Concepción, Chile. 


\section{LITERATURE CITED}

1. Gallardo, V. A. 1963. Notas sobre la densidad de la fauna bentonica en el sublitoral del Norte de Chile. Gayana Zool, 10:315 .

2. Gallardo, V. A. 1977. Large benthic microbial communities in sulphide biota under Peru-Chile subsurface countercurrent. Nature (London) 268:331-332.

3. Kellenberger, E., A. Ryter, and J. Sechaud. 1958. Electron microscope study of DNA-containing plasms. II. Vegetative and mature phage DNA as compared with normal bacterial nucleoids in different physiological states. J. Biophys. Biochem. Cytol. 4:671-676.

4. Koppe, F. 1924. Die Schlammflora der ostholsteinischen Seen und des Bodensees. Arch. Hydrobiol. 14:619-672.
5. Leadbetter, E. R. 1974. Genus I. Beggiatoa Trevisan, p. 113-114. In R. E. Buchanan and N. E. Gibbons (ed.), Bergey's manual of determinative bacteriology, 8 th ed. The Williams \& Wilkins Co., Baltimore.

6. Maier, S. 1974. Genus III. Thioploca Lauterborn, p. 115-116. In R. E. Buchanan and N. E. Gibbons (ed.), Bergey's manual of determinative bacteriology, 8 th ed. The Williams \& Wilkins Co., Baltimore.

7. Rosenberg, R., W. E. Arntz, E. C. de Flores, L. A. Flores, G. Carabajal, I. Finger, and J. Tarazona. 1983. Benthos biomass and oxygen deficiency in the upwelling system off Peru. J. Mar. Res. 41:263-279.

8. Venable, J. H., and R. Coggeshall. 1965. A simplified lead citrate stain for use in electron microscopy. J. Cell Biol. 25:407-408. 